\title{
Analysis on The Impact of Innovation Management toward Employee Engagement Mediated by Teamwork (Study Case at One of Banking Company in Indonesia)
}

\author{
Fahrina Yuliani ${ }^{1 *}$, Niken Ardiyanti ${ }^{1}$ \\ ${ }^{1}$ Faculty of Economics and Business, Universitas Indonesia \\ Email: fahrina.yuliani@ui.ac.id
}

\begin{abstract}
This study aims to determine the impact of employee's perception of Innovation Management toward employee engagement mediated by teamwork in one of Indonesian banks. The respondents of this study were 106 permanent employees in that company. Innovation system, competitors and technology, and new services are the variables used in this study. The study used causal steps developed by Baron \& Kenny (1986) to determine mediated result. The result demonstrates that only two out of three sub variables from innovation management: innovation system and competitors and technology that has impact on employee engagement mediated by teamwork. Both sub variables were partially mediating toward employee engagement. This study concludes that employee engagement can be maintain by a good innovation management, which can be implemented through a good teamwork.
\end{abstract}

Type of Paper: Empirical

Keywords: Innovation Management; Innovation System; Competitors and Technology; New Services; Teamwork; Employee Engagement

\section{Introduction}

Recently, the banking industry has become more competitive. In 2015, the banking industry in Indonesia put extra efforts to survive in the middle of the bad economy and high financial market risk (Marta, 2016). Hence, it is expected that the bank performance would get better and become able to set higher goals(Global Business, 2016). The first challenge that the banking industry are facing is the dynamic situation in the competition between each banking companies. Banking industry once being a conservative and static sector of economy which being tightly regulated by the government, yet the growing era of technology and globalization enforce the banking companies to enhance its business functions to compete with other competitors in the same sector (KPMG, 2007). Each banking company needs to keep pace with the innovation that emerge as the technology keep growing in every sector. In In order to cope with the dynamic situation, innovation management is needed. Innovation management has an important role in the sustainability and development of the organization (Tornjanski, Čudanov \& Săvoiu, 2015). Most of the innovation management studies are only 
in the technology sector. In contrast, its study in the banking sector is still limited. A study of innovation management in the banking industry in Turkey by Serinkan and Kiziloğlu (2015) found that there is a positive result of the implementation of innovation management among the employees in the banking industry.

Another challenge in the banking industry is how to achieve strategic goals through the development of employees. Employees are one of a company's greatest assets, which could be maintained through the implementation of employee engagement. Employee engagement itself is a positive behavior or feeling from the employees toward their own organizations that they have worked with (Febriansyah, 2011). However, based on the Gallup's research in $2014,68.5 \%$ of the employees feel disengaged (Bariso, 2015).

One of the biggest banking company in Indonesia, Bank $\mathrm{X}$, also face this problem. Based on the employee survey held by Bank X in 2015 stated that the level of overall employee engagement in that company is $67.52 \%$, while the disengagement level in passive category reach $32.87 \%$. Only $6.86 \%$ of employees is on the highly-engaged category. Moreover, the level of passive disengaged employees is $32.47 \%$. Even though Banx X is knowns as one of the biggest and most profitable banks in 2015, it still needs to improve the quality of its employees. Otherwise, Bank X, which was established a hundred year ago, will be left behind.

\section{Literature Review}

\section{$2.1 \quad$ Innovation Management and Teamwork}

Innovation is defined by Peter Drucker as a useful information for employees who work in companies that each have different capabilities and knowledge so every each of them has an opportunity to be more productive (Serinkan \& Kiziloğlu, 2015). Innovation management is a difference in form, quality or circumstances from time to time in management activities within an organization, where changes that occur is still new or had never done before (Birkinshaw, Hamel \& Mol, 2008).

Serinkan and Kiziloğlu (2015) in their study stated that innovation management consists of three dimensions: innovation system, competitor and technology, and new services. Innovation system is a framework that encompass the processes of organizational activities, the need of support from the organization's stakeholders, the need of organizational policies regarding innovative behavior from the member of organization and agents of change in the organization in order to implement the innovation system (Iizuka, 2013).

Competitors and technology are illustrated by how the organization's attitude toward the innovation management compared to other competitors, such as how the organization tries to describe the benefits from innovation and the organization's competitive advantages regarding innovation (Serinkan \& Kiziloğlu, 2015). New services are reflected on how the organization's response to innovative service system. For instance, how the managers allocate their time and resources to the employees who want to innovate is the example of response to innovative service system (Serinkan \& Kiziloğlu, 2015).

Based on Serinkan and Kiziloğlu (2015) study, innovation management has a positive impact 
on the development of the employees through the teamwork. Teamwork is a process of how members in a team can interact to achieve the team's goals, where each team member already has their respective roles and responsibilities (Volkov \& Volkov, 2014). Individuals must understand how to coordinate in their work and all interpersonal issues must be identified and resolved to achieve an effective teamwork. The employees will contribute more in the teamwork if they believe on the superiority of the innovation management. Thus, consistent with the ideas from the study (Serinkan \& Kiziloğlu, 2015), the hypotheses for this research are as follow:

Hypothesis 1: innovation system as a part of innovation management gives impact on teamwork

Hypothesis 2: competitors and technology as a part of innovation management gives impact on teamwork

Hypothesis 3: new services as a part of innovation management gives impact on teamwork

\subsection{Employee Engagement and Teamwork}

The definition of employee engagement is varied among the practitioners, companies and researchers (Swarnalatha \& Prasanna, 2013). Dessler (2013) defined employee engagement as a psychological form of involvement and commitment to finish the job. Rothwell described employee engagement as a positive attitude towards the job (Chat-Uthai, 2014). The studies about employee engagement itself had been done before by some previous researchers, and one of the study involved the dimensions of the employee engagement.

Most academic research on engagement used the Utrecth Work Engagement Scale (UWES), which a brief, valid and reliable questionnaire that is based on the definition of employee engagement as a combination of the dimension of vigour, dedication and absorption (Schaufeli, Salanova, Gonzalez-Roma \& Bakker, 2002). Vigour is a high spirit and desire to contribute to the work as well as persistence regardless of any circumstances. Dedication is a sense of meaningfulness, challenged and feeling proud, enthusiastic and inspired in work. Absorption defines as a condition where an employee feels very focused while doing his work until he is not aware of the time and finds it difficult when separating from the job.

Teamwork is being considered as a crucial success factors for the innovation-based organizations or the organizations that surrounded by the high level of competition (Dayan \& Benedetto, 2009, since it could improve the company's performances. Based on the employee survey from one of banking industries in Indonesia, one of the factor that gives an impact in developing the employee engagement is the aspect of teamwork. This is consistent with the research done by Anitha J (2013) about the factors affecting employee, which stated that teamwork is one of the strong factor that gives impact on employee engagement and company's performances. Thus, consistent with the idea from the aforementioned study, the hypotheses for this research are as follow :

Hypothesis 4: teamwork gives impact on employee engagement

\subsection{Teamwork as a Mediator}

Astudy by Serinkan and Kiziloğlu (2015) has confirmed the impact of innovation management 


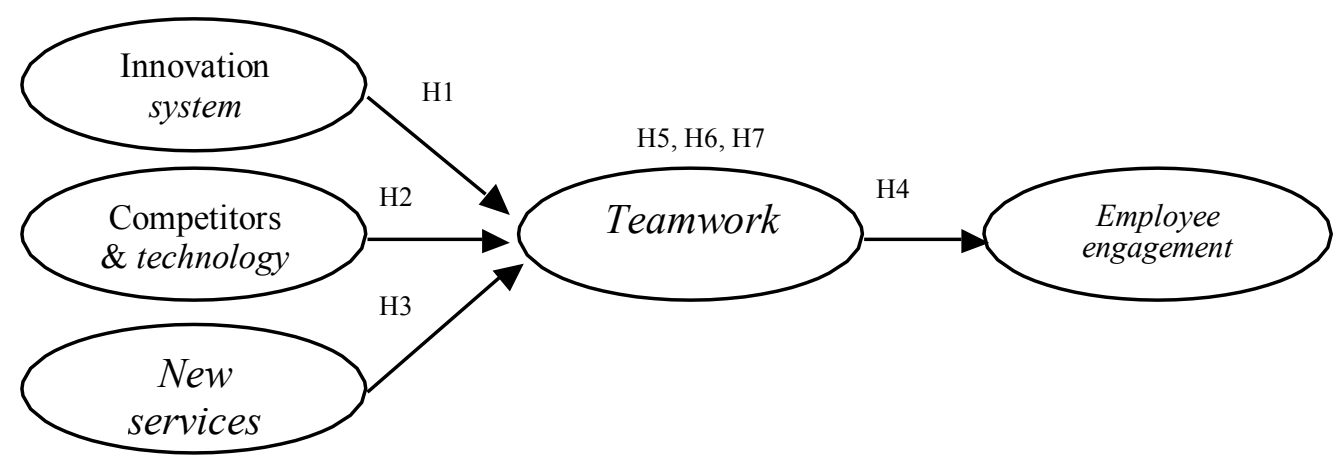

Source : Serinkan and Kiziloğlu (2015) and Anitha J. (2013), modified by researcher.

Figure 1. Research Model

on teamwork, and how teamwork affects employee engagement (Anitha J, 2013). Therefore, in this research, the authors proposed the combination of these two studies with the hypotheses as follow :

Hypothesis 5: teamwork mediates the effect of innovation system towards employee engagement

Hypothesis 6: teamwork mediates the effect of competitors and technology towards employee engagement

Hypothesis 7: teamwork mediates the effect of new services towards employee engagement

\section{Research Methodology}

The research was conducted in one of the Indonesia banking companies' headquarter office The method of this study is based on previous study by Serinkan and Kiziloğlu (2015), which also conducted in the banking industry in Turkey. This study chose to focus on Bank X's headquarter because based on the employee engagement survey held by the bank, the level of highly engaged employees in the headquarter office is the lowest compared to other units of Bank X. Moreover, the researcher selected Bank X because it is known as one of the banking companies which is always engaged in innovation but has a low level of highly engaged employees $(6,86 \%)$. However, the level of engaged employee (highly or passively disengaged) in 2015 is about $67,52 \%$, increased from the previous year which only $67,13 \%$. Hence, this study was conducted to find out whether the employees' perception of innovation management has important roles toward employee engagement.

The sampling method used in this study is a non-probability sampling, in which the elements in the population do not have the same probability to be selected in the study (Sekaran, 2003). Non-probability sampling technique which was chosen is purposive sampling, which is based on the status of employment. The sample of this study was permanent employees in headquarter office of Bank X. The population of this research is 1.000 employees from headquarter office of Bank X. The author refers to the first rule of thumb proposed by Roscoe (in Sekaran, 2003) and the Slovin's sampling size formula.

Normatively, the respondent needed for this research is around 285 respondents (based on Slovin's sampling size formula). The data was collected using survey from respondents via offline questionnaire and the questionnaire itself is in form of close-ended questions 
Table 1. Demographic Data

\begin{tabular}{cl}
\hline Demographic Categories & \multicolumn{1}{c}{ Classifications } \\
\hline Age & $\geq 20-<25(31.1 \%) ; \geq 25-<30(47.2 \%) ;$ \\
& $\geq 30-<34(17.9 \%) ; \geq 35-<40(3.8 \%)$ \\
\hline \multirow{2}{*}{ Position } & Manager's Assistant (21.7\%); Junior/Staff/Senior $(47.2 \%) ;$ Head of Division $(2.8 \%) ;$ \\
& Special Worker $(0.9 \%) ;$ Executor $(8.5 \%) ;$ Admin Staff $(11.3 \%) ;$ Manager/Vice of Head \\
& Division $(0.9 \%) ;$ Supervisor $(6.6 \%)$ \\
\hline Education & D1/D2/D3 (13.2\%); S1 $(81.1 \%) ;$ S2 $(4.7 \%) ;$ S3 $(0.9 \%)$ \\
\hline \multirow{2}{*}{ Job Tenure } & Less than 2 years $(32.1 \%) ; \geq 2-<3$ years $(14.2 \%) ; \geq 3-<4$ years $(24.5 \%) ; \geq 5-<8$ \\
& years $(22.6 \%) ;$ more than 10 years $(6.6 \%)$ \\
\hline Source : researcher's processed data using SPSS 20.0
\end{tabular}

Table 2. Hypotheses Testing

\begin{tabular}{cllcc}
\hline \multicolumn{1}{c}{ Hypotheses } & Result & R Square & $\begin{array}{c}\text { Standardized } \\
\text { Coefficient Beta }\end{array}$ \\
\hline H1 & $\begin{array}{l}\text { Innovation system as a part of innovation } \\
\text { management gives impact on teamwork }\end{array}$ & Proven & 0.204 & 0.451 \\
\hline H2 & $\begin{array}{l}\text { Competitors and technology as a part of } \\
\text { innovation management gives impact on } \\
\text { teamwork }\end{array}$ & Proven & 0.176 & 0.530 \\
\hline H3 & $\begin{array}{l}\text { New services as a part of innovation } \\
\text { management gives impact on teamwork }\end{array}$ & Not proven & 0.006 & 0.080 \\
\hline H4 & $\begin{array}{l}\text { Teamwork gives impact on employee } \\
\text { engagement }\end{array}$ & Proven & 0.174 & 0.474 \\
\hline H5 & $\begin{array}{l}\text { Teamwork mediates the effect of innovation } \\
\text { system towards employee engagement }\end{array}$ & $\begin{array}{l}\text { Proven (Partial } \\
\text { mediation) }\end{array}$ & 0.353 & 0.276 \\
\hline H6 & $\begin{array}{l}\text { Teamwork mediates the effect of } \\
\text { competitors and technology towards } \\
\text { employee engagement }\end{array}$ & $\begin{array}{c}\text { Proven (Partial } \\
\text { mediation) }\end{array}$ & 0.229 & -0.135 \\
\hline Source : researcher's processed data using SPSS 20.0 & Not Proven & 0.192 & \\
\hline
\end{tabular}

using 6-point Likert scale. The demographic data were given using multiple choice. The data that has been collected and already tested its validity and reliability is 106 responses. This research is a causal research between innovation management, teamwork and employee engagement. Thus, the model for this research shown in Figure 1.

\section{Results and Discussion}

Results are shown in Table 1 and Table 2.

\subsection{The Effect of Innovation System towards Teamwork and Employee Engagement}

This study indicates that innovation management has an impact on teamwork and employee engagement. Innovation system, as one of the dimensions of innovation management, affects teamwork, with the R Square of $20.4 \%$ and standardized coefficient beta of 0.451 . The finding is consistent with the study by Serinkan and Kiziloğlu (2015) which stated that innovation system affects teamwork. The only difference is that the number of the beta from the previous study is only 0.347 , whether in this study the beta is 0.451 .

Innovation system is perceived by the participants as a key factor of a successful performance in the company. In the middle of a dynamic competition between banking industries, the need for innovation is increasing, since it could lead to a better teamwork. If the company encourages its employees to implement the innovation system, the employees will work 
together to achieve the strategic goals. Moreover, teamwork partially mediates the effect of innovation system towards the employee engagement with the R Square of $35.3 \%$ and standardized coefficient beta of 0.474 . From this result, innovation system as a part of innovation management gives an impact to employee engagement, whether it is through the teamwork or not. But based on the beta, employee engagement could be enhanced more through the teamwork instead of without teamwork.

The Effect of Competitors and Technology towards Teamwork and Employee Engagement

Competitors and technology could also affect both eamwork and employee engagement variables. From the data, the R Square is $17.6 \%$ with the standardized coefficient beta of 0.530. This finding also consistent with the study from Serinkan and Kiziloglu (2015) which stated that competitors and technology can also affecting the teamwork. In addition, teamwork also partially mediates the effect of competitors and technology towards employee engagement. It means that whether there is a teamwork or not, competitors and technology still affecting employee engagement. However, the effect will be greater if there is a better teamwork to achieve a better engagement among the employees.

Based on the participants' response, their company usually becomes the first one who brings the innovative banking products and services compared with the other competitors. This competitive advantage is not inseparable with the role of teamwork within the organization. They are targeting the innovative ideas for their company so that they need to work together with the other employees within the company. From a better teamwork, the participants responses that it could enhanced their engagement with the company because they feel that they belong to the company and their contribution in teamwork could give a positive impact on the company's performance. This finding also consistent with the study from Anitha J. (2013) which stated that teamwork is one of the strongest determinants in employee engagement. A good relationship and teamwork between co-workers is expected to be more involved with their engagement toward the company (Anitha J., 2013). Moreover, based on the employee survey held by this banking company in 2015 , teamwork has a significant effect toward the employee engagement.

\subsection{The Effect of New Services towards Teamwork and Employee Engagement}

From the result, two sub-variables from innovation management (innovation system and competitors and technology) affected teamwork and on employee engagement. However, there is no effect on the other sub-variables of innovation management, which is new services, both toward teamwork and toward employee engagement. Serinkan and Kiziloğlu (2015) stated that new services have impact toward teamwork, yet the effect is very little. The authors processed the data based on demographic variables. According to the result, of how the participants' position in the company, participants' education level, and participants' job tenure variables have no impact on teamwork and employee engagement.

However, the result shows that age of the participants has an impact on teamwork and employee engagement. The age was divided based on generation level, which is Gen $\mathrm{X}$ and Gen Y. The result demonstrates that teamwork is a mediator between the effect of new 
services toward the employee engagement in the employees within Gen $X$. But in this case, the mediation that occur is inconsistent mediation. Mackinnon, Fairchild and Fritz (2007) suggest that inconsistent mediation can occur when in the first stage of the Baron and Kenny's causal steps is not met but the effect of mediation still occur. The effect of this mediation is seen from the number of direct effect greater that the total effect. In this case, the coefficient beta in the third stage is 0.235 while the coefficient beta at the first stage is only -0.168 , which means that the first stage is not significant, but it could mediate the effect of independent variable towards the dependent variable.

When the inconsistent mediation occurs, the mediation variable acts as a suppressor variable, in which serves to increase the influence of the independent variable to the dependent variable after the variable is entered into the regression as a predictor variable (Kenny, 2014). From this finding, even though new services does not affect employee engagement, but with the role of teamwork as a suppressor variable, there is a potential increase in the influence between new services on employee engagement, even though both of those variables have no direct impact before.

\section{Conclusion}

Based on the results above, it can be concluded that in general, innovation management affects both teamwork and employee engagement. However, one of the dimension of innovation management, new services, has no impact towards both teamwork and employee engagement (with beta only 0.08 and -0.135 for the mediation effect). But, if the analysis is based on the generation differences, new services does affect employee engagement through teamwork, even though the effect only occur in the employees within Gen X. Hence, although the overall generation differences do not affect the regression results, based on multiple regression test for Gen X, it can be a variable that can increase the influence of new services on employee engagement.

Looking back at the characteristics of Gen $\mathrm{X}$ that have started to open their mind regarding technologies but tend to be a little skeptical does not necessarily affect the engagement of the Gen X. However, if there is a teamwork within the organization, employees within the Gen $\mathrm{X}$ are given the opportunity to work with other employees beyond the Gen $\mathrm{X}$, such as Gen Y. Gen Y with technological-minded characteristics can help Gen X to provide information related to the latest technologies and services available in the company. Gen Y can also be convinced the Gen X the importance of technology benefits through the teamwork. Gen X then will be increasingly engaged with the company and its innovation because they feel comfortable with the technology and innovation that exist within the company after they got guidance from the Gen Y.

\section{Limitation of Study}

There are some limitations of this study. First, this study can only gather a limited number of respondents. Based on sampling size by Slovin, the respondents needed is about 285 respondents from Bank X. However, the researcher only capable to get 106 respondents. Second, in this study, the researcher used causal step method by Baron and Kenny (1986) for the mediation analysis. However, this method cannot analyze the mediation effect simultaneously. Third, the literatures about the impact of innovation management towards 
human resource issues, especially about employee engagement issue, is still limited.

\section{Implication}

\subsection{Implication for Manager}

The company needs to consider about how the employees try to give innovative ideas (as a part of innovation system dimension), because employees are sometimes still hampered by rigid organizational structure. In addition, the company needs to consider about giving supports to the employees who want to innovate (as a part of competitors and technology dimension). The support itself could be in form of time or other resources. This support is perceived as an indirect way on how the company creates the competitive advantage (as a company try to develop its employees through giving supports). Moreover, open communication is needed in the teamwork process. Finally, the company need to consider about create the good working environment to support the teamwork process. Furthermore, this working environment is one of employee engagement drivers mentioned by Anitha J. (2013) study.

\subsection{Implication for Future Study}

From this research, it can be concluded that the study about human resources can be linked to other issues, especially in this case is related to innovation management. Even though there is still lack of literatures that discuss the relationship between innovation management and human resource issues, future study may fill this knowledge-gap. Furthermore, future study can conduct a research not only in the banking industry, but also other industries. The data collection technique can also be improved by using additional interview to the respondents to enrich the results.

\section{References}

Anitha, J. (2013). Determinants of employee engagement and their impact on employee performance. International Journal of Productivity. 63, 308-323.

Bariso, J. (2015, May 1). Here's How You Solve the Employee Engagement Problem. Retrieved December 1, 2015, from Inc Web Site: http://www.inc.com/justinbariso/here-s-how-you-solve-the-employee-engagement-problem.html

Chat-Uthai, M. (2013). Leveraging Employee Engagement Surveys Using the Turnover Stimulator Approach: A Case Study of Automotive Enterprises in Thailand. International Journal of Business and Management. 8, No.6.

Dayan, M., \& Benedetto, A.D. (2009). Antecedents and consequences of teamwork quality in new product development projects. European Journal of Innovation. 12, 129-155.

Dessler, G. (2013). Human Resource Management (13 ${ }^{\text {th }}$ ed). United States of America: Prentice Hall. 
Febriansyah, H. (2011, Agustus 16). Employee Engagement. Retrieved November 29, 2015, from HR Centro Web Site: http://www.hrcentro.com/artikel/Employee_engagement_110816.html

Global Business. (2016, Januari 6). Outlook Perbankan 2016: Optimis Tumbuh Lebih Baik. Retrieved November 29, 2015, from Global Business Web Site: http://eglobalbusiness.com/2016/01/outlook-perbankan-2016-optimis-tumbuh-lebih-baik

Iizuka, M. (2013). Innovation systems framework: still useful in the new global context?.UNU-MERIT Working Papers.

Kenny, D. A. (2014, April 9). Mediation. Retrieved May 30, 2016, from davidakenny Web site: http://davidakenny.net/cm/mediate.htm

KPMG, 2007. Banking on Innovation? The challenge for retail banks. Retrieved July 17, 2016 from KPMG Web Site: http://files.welzijn-21eeeuw.nl/BankingOnInnovation.pdf

MacKinnon, D. P., Fairchild, A. J., \& Fritz, M. S. (2007). Mediation analysis. Annual Review of Psychology, 58, 593-614

Marta, M.F. (2016, March 8). Persaingan 5 Bank Terbesar: Kinerja Kredit, Siapa yang Lebih Baik?. Retrieved November 30, 2015, from Kompas Web Site: http://bisniskeuangan.kompas.com/read/2016/03/08/182924426/Persaingan.5.Bank.Te rbesar.Kinerja.Kredit.Siapa.yang.Lebih.Baik.

Schaufeli, W.B., Salanova, M., Gonzalez-Roma, V., and Bakker, A.B. (2002). The Measurement of Engagement and Burnout: A Two Sample Confirmatory Factor Analytic Approach. Journal of Happiness Studies. 3, 71-92.

Sekaran, U. (2003). Research methods for business a skill building approach. United States of America: John Wiley \& Sons, Inc.

Serinkan, C., \& Kiziloğlu, M. (2015). Innovation Management and Teamwork: An Investigation in Turkish Banking Sector. Journal of Management Policies and Practices. 3, 94-102.

Swarnalatha, C., \& Prasanna, T.S. (2013). Employee Engagement: The Concept. International Journal of Management Research and Review. 3, 3872-3880.

Tornjanski, V., Čudanov, M., \& Săvoiu, G. 2015. A Holistic Approach To Innovation Management In Banking: A Review. Econophysics, Sociophysics \& Other Multidiciplinary Sciences Journal. 5, 8-15.

Volkov, A., \& Volkov, M. (2013). Teamwork benefits in tertiary education. Education + Training. 57, 262-278. 